J. Clin. Chem. Clin. Biochem.

Vol. 19, 1981, pp. 1067-1073

\title{
Plasma Myelin Basic Protein Assay using Gilford Enzyme Immunoassay Cuvettes
}

\author{
By N. P. Groome \\ Department of Biology, Oxford Polytechnic, Headington, U.K.
}

(Received December 18, 1980/April 24, 1981)

Summary: The assay of myelin basic protein in body fluids has potential clinical importance as a routine indicator of demyelination.

Preliminary details of a competitive enzyme immunoassay for this protein have previously been published by the author (Groome, N. P. (1980) J. Neurochem. 35, 1409-1417).

The present paper now describes the adaptation of this assay for use on human plasma and various aspects of routine data processing.

A commercially available cuvette system was found to have advantages over microtitre plates but required a permuted arrangement of sample replicates for consistent results. For dose interpolation, the standard curve could be fitted to a three parameter non-linear equation by regression analysis or linearised by the logit/log transformation.

\section{Bestimmung des basischen Myelinproteins mit Gilford Enzymimmunassay-Küvetten}

Zusammenfassung: Die Bestimmung des basischen Myelinproteins in Körperflüssigkeiten hat möglicherweise klinische Bedeutung in der Diagnostik von Demyelinisierungsprozessen.

Eine Methodé zur Messung durch „competitive enzyme immunoassay“ ist für dieses Protein vom Verfasser beschrieben worden (Groome, N. P. (1980) J. Neurochem. 35, 1409-1417).

In der vorliegenden Arbeit wird die Anpassung dieser Bestimmungsmethode für menschliches Blutplasma beschrieben und eine Routineauswertung der Meßdaten vorgestellt. Ein kommerziell erhältliches Küvettensystem ist vorteilhafter als "microtitre plates", bedarf aber einer permutierten Anordnung der identischen Proben, um zuverlässige Ergebnisse zu liefern. Die Standardkurve entspricht einer nicht-linearen Gleichung mit 3 Parametern, die mittels Regressionsanalyse erstellt wurde oder durch logit/log Transformation linearisiert werden kann.

\section{Introduction}

Myelin basic protein is nervous system specific and the major protein component of myelin (1). As such it is an ideal substance to assay in body fluids as a measure of demyelination. Such measurements may have application to head injury, stroke and multiple sclerosis patients $(2,3)$.

We have recently described the principle of an Enzyme Linked Immunoassay procedure ${ }^{1}$ ) for myelin basic protein which offers certain advantages over radioimmunoassay as a routine tool (4). We show here that the assay can be applied to plasma and describe some useful data processing procedures.

We also report our experience with Gilford immunoassay cuvettes as a solid phase. Although preferable to micro-

\footnotetext{
1) Abbreviation: ELISA = Enzyme Linked Immunoadsorbent Assay.
}

titre plates, the current batches of these cuvettes show a phenomenon termed the 'smile effect' i.e. the end wells on each strip give higher readings than those in the centre.

The effect of this on the myelin basic protein assay can be overcome by arranging the replicates of each sample in a permuted distribution. The system as described here would allow any laboratory to do routine myelin basic protein assays.

\footnotetext{
Materials and Methods

Gilford immunoassay cuvettes (lot number 102592) were obtained from Gilford Instruments Inc., Ohio. Logit-log graph paper was obtained from Heffers Bookshop, Cambridge, U.K. The ELISA for myelin basic protein was carried out essentially as described previously (4) for use in microtitre plates. It was necessary with the Gilford cuvettes to use $0.25 \mathrm{ml}$ volumes of each reagent to avoid meniscus effects, and to cover the optical path for absorbance measurement.
} 


\section{Coating of wells with antigen}

A solution of bovine myelin basic protein at $0.3 \mathrm{mg} / 1 \mathrm{in} 0.1 \mathrm{~mol} / 1$ phosphate buffer $\mathrm{pH} 6.0$ was prepared in a siliconised beaker. Bovine myelin basic protein is used instead of human myelin basic protein for coating since it is easier to obtain in a highly purified state. $0.25 \mathrm{ml}$ was placed in each cuvette and the cuvette strips stood overnight at $25^{\circ} \mathrm{C}$ in a moist atmosphere. The cuvette strips were then washed $10 \mathrm{x}$ with wash solution $(12 \mathrm{~g} / 1$ sodium chloride, $0.5 \mathrm{~g} / \mathrm{l}$ Tween 80 ), leaving them for $2 \mathrm{~h}$ in the last wash to allow loosely bound myelin basic protein to detach (5).

They were then given a distilled water rinse and allowed to air dry. Cuvette strips were then stored over silica gel until required.

\section{Preparation of plasma samples for assay}

Fresh citrated blood samples were centrifuged to obtain plasma. These were either analysed immediately or stored at $-20^{\circ} \mathrm{C}(6)$.

Each plasma sample was mixed with one volume of $0.2 \mathrm{~mol} / \mathrm{l}$ citrate buffer $\mathrm{pH} 3.7$ and a further volume of $0.05 \mathrm{~mol} / 1$ phosphate buffer pH 7.0 containing $12 \mathrm{~g} / 1$ sodium chloride, $0.5 \mathrm{~g} / 1$ Tween 80 and $0.25 \mathrm{~g} / 1$ calf thymus histones. The solution was then heated at $100^{\circ} \mathrm{C}$ for 5 minutes, during which time the bulk of the plasma protein precipitates. Myelin basic protein is left quantitatively in solution (6). After centrifugation the supernatant was used for ELISA.

\section{Procedure}

\section{ELISA Stage 1}

A control sample was prepared by mixing equal volumes of the supernatant from pooled normal human plasma with a $1: 160000$ dilution of a rabbit anti-human myelin basic protein serum (kk42). Antiserum dilution was made in $0.2 \mathrm{~mol} / \mathrm{l}$ disodium hydrogen phosphate containing $12 \mathrm{~g} / \mathrm{l}$ sodium chloride, $0.5 \mathrm{~g} / \mathrm{l}$ Tween 80 and $0.5 \mathrm{~g} / 1$ calf thy mus histones. This serum reacts well with human and bovine myelin basic protein. Histones are always added to the buffers immediately before use to prevent the development of inhibitory activity (6).

The standard curve was prepared by adding known amounts of human myelin basic protein (courtesy of $M$. Kies) to pooled normal human plasma. Samples were citrated and boiled and mixed with antiserum as for the control. A blank was prepared by mixing an equal volume of the supernatant from treated normal plasma with buffer alone. The solutions were allowed to stand at room temperature for $4 \mathrm{~h}$ before the next stage.

\section{ELISA Stage 2 (as finally adopted)}

Twenty $0.4 \mathrm{ml}$ aliquots of the control mixture were placed in a permuted distribution in ten cuvette strips occupying the position labelled $A$ and $B$ as in table 2. Ten aliquots of each of the standards occuped positions $C, D, E, F, G, H$ and $I$ and ten aliquots of blank occupied $J$. The reasons for adopting this permuted distribution are described in a later section. The cuvette strips were then placed in a moist box overnight at room temperature on a device providing slight agitation.

\section{ELISA Stage 3}

The cuvette strips were emptied by shaking and then washed $10 \times$ with wash solution. To remove the last traces of liquid they were struck firmly several times onto paper towelling. $0.25 \mathrm{ml}$ of goat anti rabbit-IgG/peroxidase conjugate at a dilution of 1:5000 in conjugate dilution buffer (4) was then added. This was allowed to react for $6 \mathrm{~h}$ at room temperature with the cuvettes in a moist box, again with slight agitation.

\section{ELISA Stage 4}

The cuvette strips were washed and emptied as before. Then $0.25 \mathrm{ml}$ of peroxidase substrate (4) was added and incubation carried out overnight at room temperature with agitation. The experiments reported here all used $0.1 \mathrm{~mol} / 1$ phosphate buffer pH 7.0 as reaction buffer (4). Recently we have found that faster rates of reaction can be achieved in $0.1 \mathrm{~mol} / \mathrm{l}$ citrate buffer $\mathrm{pH} 4.0$, other conditions remaining the same.

\section{ELISA Stage 5}

The optical faces of the cuvette strips were wiped with tissue and the absorbance at $420 \mathrm{~nm}$ at all positions measured with a Gilford cuvette reader referenced to air.

\section{ELISA Stage 6 .}

The ten absorbance values for each cuvette strip at a time were typed into a computer, which then carries out the following routine calculations:

1. Calculates the average of the A's, B's, C's etc. from the permuted distribution.

2. Subtracts the blank.

3. Averages $A$ and $B$ and designates this the $100 \%$ level, in the absence of a competitor.

4. Expresses the average of C, D, E etc. as a \% of the control.

\section{Dose interpolation}

Linearisation of the standard curve could be obtained by plotting (\% of the control) versus myelin basic protein concentration on Logit log graph paper. Alternatively the data were fitted by computer to a three parameter non-linear equation by regression analysis (7). The latter method was used routinely.

\section{Procedure for unknown samples}

Plasma samples containing unknown amounts of myelin basic protein were citrated and boiled as for the standard curve. For each eight samples to be analysed ten strips are required in addition to those for the standard curve. Positions $A$ and $B$ are again used for controls but now all eight remaining positions $(\mathrm{C}-\mathrm{J})$ are used for unknowns. The (\% of the control) for each unknown is calculated and the corresponding myelin basic protein concentration calculated from the previously determined regression equation.

\section{Results}

\section{$\mathrm{A}_{3}$ competitive $\mathrm{ELISA}$}

The $A_{3}$ competitive assay principle (8) has not been widely used. A similar assay to that described here has, however, been applied to factor VIIII related antigen (9), although this was of much lower sensitivity. The assay principle is shown in figure 1. Full details of the initial development of the assay for myelin basic protein have been described elsewhere (4).

\section{Adaptation of the ELISA method to use Gilford cuvettes}

This required few changes from the method using microtitration plates (4). A minimum volume of $0.25 \mathrm{ml}$ was used to avoid meniscus effects and to cover the optical path for the final absorbance measurement. Figure 2 shows some of the results of an myelin basic protein assay in which all ten positions on a separate strip were used to replicate each dose level. The replicates within one strip did not give values randomly distributed about a mean but a characteristic pattern of reactivity with a central trough. Quality control procedures on Gilford cuvettes are claimed to be rigorous and do predict this phenomenon termed the 'smile' effect ( $U$ ). The magnitude of the smile effect may well vary according to the nature of the absorbed material and the principle of the particular immunoassay. It should be noted that Gilford cuvettes are designed for use in an automáted processor 
Competitive, heterogenous method for detection of antigen

Step 1

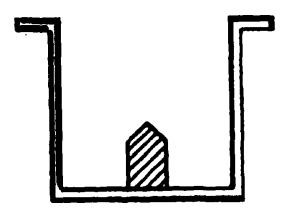

Step 2

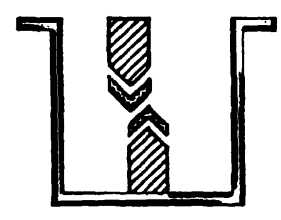

Sample antigen and specific antibody are added. Bound and free antigen compete for antibody. Bound and free complexes are separated by washing.

Step 3

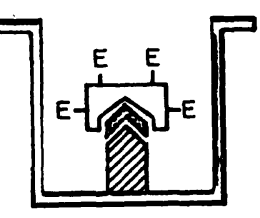

Enzyme-labelled antiglobulin is added and binds to antibody. Frec conjugate is removed by washing.

Step 4

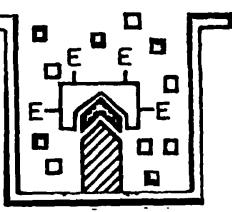

Chromogenic substrate is added. The optical density is reduced in proportion to the amount of competing antigen.

A standard curve is prepared of a range of competing antigen concentrations. The concentration of an unknown sample antigen is determined from the standard curve.

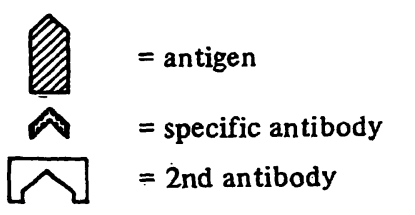

$$
\begin{aligned}
E= & \text { enzyme } \\
\square= & \text { substrate } \\
\square= & \text { coloured substrate after } \\
& \begin{array}{l}
\text { enzyme-cataly sed } \\
\text { reaction }
\end{array}
\end{aligned}
$$

Fig. 1. The principle of the $A_{3}$ Competitive Immunoadsorbent Assay.

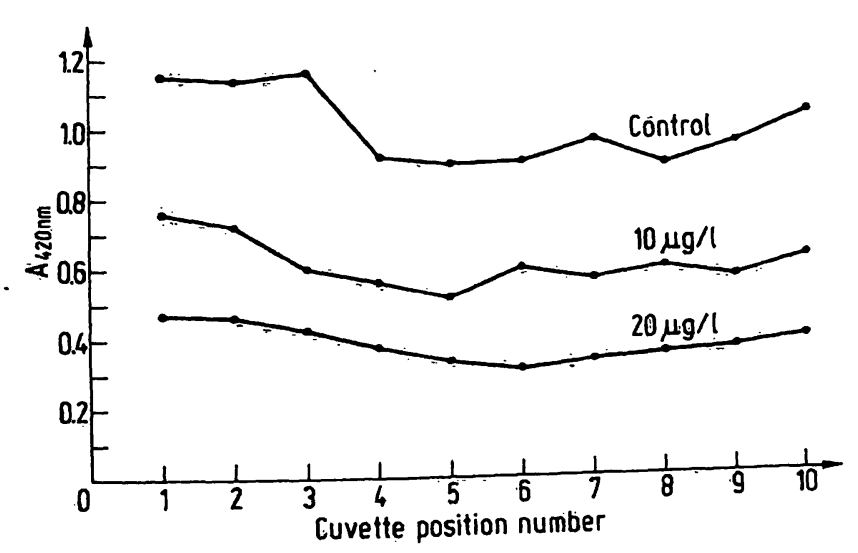

Fig. 2. Myelin basic protein immunoassay in Gilford cuvettes. All the replicates at each dose level were placed on one cuvette strip. Values within a strip were not randomly distributed about a mean but had a characteristic distribution, termed the 'smile' effect.
(PR50) so that random errors due to variations in the washing treatments and reagent additions will be somewhat greater in the present study than if the whole assay was automated. Nevertheless, many workers will require to use these cuvettes as they are here and will presumably find these results more typical.

\section{Further characterisation of the smile effect}

To define more precisely the reactivity of the different cuvette positions in this assay the following experiment was done. Fifteen strips were coated identically with myelin basic protein and were then reacted with anti myelin basic protein serum, exactly as in the control for figure 2. The assay was then completed. The results suggested that the smile was slightly lop-sided (fig. 3 , tab. 1).

Furthermore, considerable variation occurred in corresponding well positions from strip to strip. The end positions were more variable than the others. This variation could have two components (1) random error (2) systematic error due to variations in the mean from strip to strip. The latter could have two causes. Either variation in experimental strip handling or manufacturing differences. The data of table 1 supported the idea that systematic variation was the major cause, of betweenstrip variability since it can be seen that some strips gave high values at all positions (e.g. marked $\bullet$ ), whilst others gave low values at all positions (e.g. marked o).

\section{Attempts to minimise strip to strip variation}

Since the initial experiments shown in figure 3 and table 1 were done efforts have been made to make the washing procedures more reproducible. Although these slightly reduced the systematic variation from strip to strip they did not eliminate it. Thus, consideration was given as to the best method of using these cuvette strips to allow the most reliable comparisons between samples.

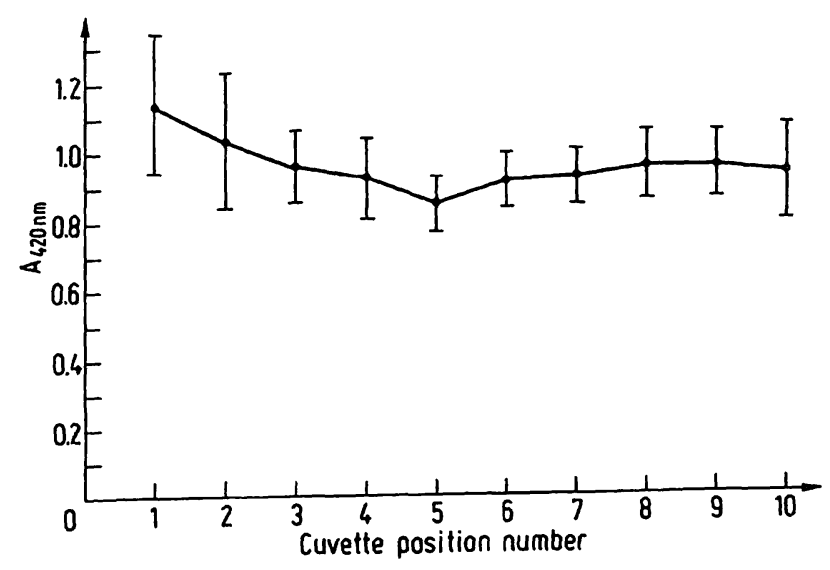

Fig. 3. Further characterisation of the 'smile' effect. Fifteen cuvette strips were used entirely for control samples in a myelin basic protein assay.

Between strip mean $(n=15)$ for each cuvette position. Bars show \pm 1 standard deviation. 
Tab. 1. Actual data (absorbance at $420 \mathrm{~nm}$ ) for ten of the cuvette strips used for Fig. 3.

$0=$ strips giving high values at all positions $0=$ strips giving lower values

The data also show the permutation system used to derive a mean in a way which cancels out the smile effect.

\begin{tabular}{|c|c|c|c|c|c|c|c|c|c|c|c|}
\hline & \multicolumn{11}{|c|}{ Cuvette position number } \\
\hline & 1 & 2 & 3 & 4 & 5 & 6 & 7 & 8 & 9 & 10 & \\
\hline Strip 1 & $\begin{array}{l}\mathbf{A} \\
1.135\end{array}$ & $\begin{array}{l}\text { B } \\
1.045\end{array}$ & $\begin{array}{l}\mathrm{C} \\
1.040\end{array}$ & $\begin{array}{l}\text { D } \\
0.998\end{array}$ & $\begin{array}{l}E \\
0.89\end{array}$ & $\begin{array}{l}\text { F } \\
0.969\end{array}$ & $\begin{array}{l}\text { G } \\
1.004\end{array}$ & $\begin{array}{l}\mathrm{H} \\
1.096\end{array}$ & ${ }_{1.120}$ & $\begin{array}{l}\mathrm{J} \\
1.000\end{array}$ & $\bullet$ \\
\hline Strip 2 & $\begin{array}{l}\mathrm{J} \\
1.008\end{array}$ & $\begin{array}{l}\text { A } \\
0.896\end{array}$ & $\begin{array}{l}\text { B } \\
0.985\end{array}$ & $\begin{array}{l}\mathrm{C} \\
0.702\end{array}$ & $\begin{array}{l}D \\
0.809\end{array}$ & $\begin{array}{l}E \\
0.860\end{array}$ & $\begin{array}{l}\text { F } \\
0.949\end{array}$ & $\begin{array}{l}\mathbf{G} \\
1.070\end{array}$ & $\begin{array}{l}\mathrm{H} \\
0.860\end{array}$ & $\begin{array}{l}\text { I } \\
0.857\end{array}$ & \\
\hline Strip 3 & $\begin{array}{l}\text { I } \\
1.303\end{array}$ & $\begin{array}{l}\mathrm{J} \\
1.150\end{array}$ & $\begin{array}{l}\mathrm{A} \\
1.080\end{array}$ & $\begin{array}{l}\text { B } \\
0.927\end{array}$ & $\begin{array}{l}C \\
0.834\end{array}$ & $\begin{array}{l}D \\
0.876\end{array}$ & $\begin{array}{l}\mathrm{E} \\
1.138\end{array}$ & $\begin{array}{l}\mathrm{F} \\
0.908\end{array}$ & $\begin{array}{l}G \\
1.038\end{array}$ & $\begin{array}{l}\mathrm{H} \\
0.928\end{array}$ & \\
\hline Strip 4 & $\begin{array}{l}\mathrm{H} \\
0.907\end{array}$ & $\begin{array}{l}\text { I } \\
0.916\end{array}$ & $\begin{array}{l}J \\
0.780\end{array}$ & $\begin{array}{l}\text { A } \\
0.895\end{array}$ & $\begin{array}{l}\text { B } \\
0.698\end{array}$ & $\begin{array}{l}C \\
0.892\end{array}$ & $\begin{array}{l}\mathrm{D} \\
0.830\end{array}$ & $\begin{array}{l}\mathrm{E} \\
0.888\end{array}$ & $\begin{array}{l}F \\
0.720\end{array}$ & $\begin{array}{l}\text { G } \\
0.690\end{array}$ & $\circ$ \\
\hline Strip 5 & $\begin{array}{l}G \\
1.273\end{array}$ & $\begin{array}{l}H \\
1.020\end{array}$ & $\begin{array}{l}I \\
0.790 \text { 。 }\end{array}$ & $\begin{array}{l}\mathrm{J} \\
0.787\end{array}$ & $\begin{array}{l}A \\
0.665\end{array}$ & $\begin{array}{l}\text { B } \\
0.700\end{array}$ & $\begin{array}{l}C \\
0.716\end{array}$ & $\begin{array}{l}\mathrm{D} \\
0.815\end{array}$ & $\begin{array}{l}\mathrm{E} \\
0.770\end{array}$ & $\begin{array}{l}F \\
0.849\end{array}$ & $\circ$ \\
\hline Strip 6 & $\begin{array}{l}F \\
1.438\end{array}$ & $\begin{array}{l}\text { G } \\
1.298\end{array}$ & $\begin{array}{l}\mathrm{H} \\
1.098\end{array}$ & $\begin{array}{l}\text { I } \\
1.068\end{array}$ & $\begin{array}{l}\mathbf{J} \\
0.956\end{array}$ & $\begin{array}{l}\text { A } \\
0.990\end{array}$ & $\begin{array}{l}\text { B } \\
1.018\end{array}$ & $\begin{array}{l}C \\
1.048\end{array}$ & $\begin{array}{l}\mathrm{D} \\
1.110\end{array}$ & $\begin{array}{l}\mathrm{E} \\
1.058\end{array}$ & \\
\hline Strip 7 & $\begin{array}{l}\mathrm{E} \\
1.250\end{array}$ & $\begin{array}{l}F \\
0.981\end{array}$ & $\begin{array}{l}G \\
0.950\end{array}$ & $\begin{array}{l}\mathrm{H} \\
0.978\end{array}$ & $\begin{array}{l}I \\
0.802\end{array}$ & $\begin{array}{l}\mathbf{J} \\
0.907\end{array}$ & $\begin{array}{l}\text { A } \\
0.950\end{array}$ & $\begin{array}{l}\tilde{B} \\
0.950\end{array}$ & $\begin{array}{l}C \\
0.910\end{array}$ & $\begin{array}{l}D \\
0.770\end{array}$ & \\
\hline Strip 8 & $\begin{array}{l}\mathrm{D} \\
1.495\end{array}$ & $\begin{array}{l}\mathrm{E} \\
1.170\end{array}$ & $\begin{array}{l}\mathrm{F} \\
1.001\end{array}$ & $\begin{array}{l}G \\
1.150\end{array}$ & $\begin{array}{l}\mathrm{H} \\
1.070\end{array}$ & $\begin{array}{l}\text { I } \\
1.010\end{array}$ & $\begin{array}{l}\mathrm{J} \\
1.130\end{array}$ & $\begin{array}{l}A \\
0.980\end{array}$ & $\begin{array}{l}\text { B } \\
1.220\end{array}$ & $\begin{array}{l}\mathrm{C} \\
1.350\end{array}$ & \\
\hline Strip 9 & $\begin{array}{l}\mathrm{C} \\
1.340\end{array}$ & $\begin{array}{l}D \\
0.978\end{array}$ & $\begin{array}{l}E \\
1.005\end{array}$ & $\begin{array}{l}F \\
0.833\end{array}$ & $\begin{array}{l}\text { G } \\
0.817\end{array}$ & $\begin{array}{l}\mathrm{H} \\
0.802\end{array}$ & $\begin{array}{l}\text { I } \\
0.828\end{array}$ & ${ }^{\mathrm{J}} .020$ & $\begin{array}{l}\text { A } \\
0.990\end{array}$ & $\begin{array}{l}\text { B } \\
0.950\end{array}$ & \\
\hline Strip 10 & $\begin{array}{l}\mathrm{B} \\
1.320\end{array}$ & $\begin{array}{l}\mathrm{C} \\
1.190\end{array}$ & $\begin{array}{l}\mathrm{D} \\
1.080\end{array}$ & $\begin{array}{l}\mathrm{E} \\
1.150\end{array}$ & $\begin{array}{l}F \\
0.936\end{array}$ & $\begin{array}{l}\mathrm{G} \\
1.020\end{array}$ & $\begin{array}{l}\mathrm{H} \\
1.070\end{array}$ & $\begin{array}{l}\text { I } \\
1.170\end{array}$ & $\begin{array}{l}\mathrm{J} \\
1.240\end{array}$ & $\begin{array}{l}\mathrm{A} \\
1.000\end{array}$ & $\bullet$ \\
\hline
\end{tabular}

Mean

Sample 1.A $=0.958 \quad$ Sample 2.B $=0.981$

Sample 6.F $=0.958 \quad$ Sample 7.G $=1.031$

Coefficient of variation for $\mathrm{A}-\mathrm{J}=2.4 \%$
Sample 3.C $=1.002$

Sample 8. $\mathrm{H}=\mathbf{0 . 9 8 3}$
Sample 4.D $=0.976$

Sample 9.I $=0.986$
Sample 5.E $=1.018$

Sample 10.J $=0.998$
A procedure for using the Gilford cuvettes for precise sample comparisons

Before the myelin basic protein assay could be used with confidence for the routine analysis of clinical samples several questions needed to be considered. Firstly, what level of confidence was required in the percentages of the control value determined at each dose level? Secondly, how many replicates were required to achieve this degree of confidence? Thirdly, how were the replicates at each dose level to be distributed? It was decided that the precision would be adequate if an absorbance $7 \%$ below the control level was significant at the $95 \%$ confidence level. The distribution of sample replicates was critically important for this standard to be met. If the replicates (e.g. $N=5$ ) at each dose level were all arranged on a single strip the smile effect would cause the two halves of the strip to differ to start with. If the whole strip was used for ten replicates, although the smile effect was overcome, the assay then became unduly senisitive to systematic differences between strips caused by handling or manufacturing differences. It was not justifiable to assume that the standard deviation of

strip means $=\frac{S D \text { (within strip) }}{\sqrt{10}}$. The SD $($ within strip)

is largely caused by the smile effect and does not allow one to assess the magnitude of between strip variation.
Another possible arrangement would place all the replicates of one sample in well position 1 on a series of strips, and the other samples in positions $2,2,2,3,3,3$, etc. This arrangement would also allow the distortion of the assay results by the smile effect.

A logical solution to the problem posed above would be to permute the sample replicates as shown in table 2 . Early results soon confirmed that samples could be very precisely and unambiguously compared by this method. The standard deviation of permuted sample means within a ten strip array has a standard deviation of about $2.5 \%$ (tab. 1). The following procedure has now been adopted routinely for the analysis of unknown. Ten strips are used for two controls (set A and set B) seven standards (C-I) and one blank (J). Each successive ten strips also contain two controls but now have unknown samples at all the remaining positions. A simple computer programme analyses the data in the following way:

1) Absorbance values are requested strip by strip for each batch of ten strips.

2) The mean of the permuted replicates for A, B, C, etc. is calculated.

3) The blank is subtracted.

4) $A$ and $B$ are averaged to give the control value and all the standards are calculated as a percentage of the control. 
Tab. 2. Plasma myelin basic protein assay using a permuted distribution of sample replicates. $A$ and $B$ are controls, $C-I$ standards and $\mathrm{J}$ a blank. The figure shows the actual absorbance values at $420 \mathrm{~nm}$ and subsequent data processing which is done routinely with the help of a simple computer programme. Details as described in "Methods".

\begin{tabular}{|c|c|c|c|c|c|c|c|c|c|c|}
\hline & \multicolumn{10}{|c|}{ Cuvette position number } \\
\hline & 1 & 2 & 3 & 4 & 5 & 6 & 7 & 8 & 9 & 10 \\
\hline Strip 1 & $\begin{array}{l}\text { A } \\
0.961\end{array}$ & $\begin{array}{l}\text { B } \\
0.796\end{array}$ & $\begin{array}{l}C \\
0.691\end{array}$ & $\begin{array}{l}D \\
0.638\end{array}$ & $\begin{array}{l}E \\
0.509\end{array}$ & $\begin{array}{l}F \\
0.409\end{array}$ & $\begin{array}{l}G \\
0.354\end{array}$ & $\begin{array}{l}H \\
0.290\end{array}$ & $\begin{array}{l}\text { I } \\
0.269\end{array}$ & $\begin{array}{l}\text { J } \\
0.197\end{array}$ \\
\hline Strip 2 & $\begin{array}{l}\mathbf{J} \\
0.179\end{array}$ & $\begin{array}{l}\mathrm{A} \\
1.283\end{array}$ & $\begin{array}{l}\text { B } \\
1.165\end{array}$ & $\begin{array}{l}\mathrm{C} \\
1.247\end{array}$ & $\begin{array}{l}D \\
0.814\end{array}$ & $\begin{array}{l}\mathrm{E} \\
0.774\end{array}$ & $\begin{array}{l}F \\
0.596\end{array}$ & $\begin{array}{l}G \\
0.517\end{array}$ & $\begin{array}{l}\mathrm{H} \\
0.398\end{array}$ & $\begin{array}{l}\text { I } \\
0.381\end{array}$ \\
\hline Strip 3 & $\begin{array}{l}\text { I } \\
0.391\end{array}$ & $\begin{array}{l}\mathrm{J} \\
0.278\end{array}$ & $\begin{array}{l}\text { A } \\
1.015\end{array}$ & $\begin{array}{l}\text { B } \\
1.001\end{array}$ & $\begin{array}{l}C \\
0.798\end{array}$ & $\begin{array}{l}D \\
0.795\end{array}$ & $\begin{array}{l}E \\
0.586\end{array}$ & $\begin{array}{l}F \\
0.649\end{array}$ & $\begin{array}{l}G \\
0.436\end{array}$ & $\begin{array}{l}\mathrm{H} \\
0.342\end{array}$ \\
\hline Strip 4 & $\begin{array}{l}\text { H } \\
0.386\end{array}$ & $\begin{array}{l}\text { I } \\
0.290\end{array}$ & $\begin{array}{l}\mathbf{J} \\
0.192\end{array}$ & $\begin{array}{l}A \\
0.868\end{array}$ & $\begin{array}{l}\text { B } \\
0.728\end{array}$ & $\begin{array}{l}C \\
0.756\end{array}$ & $\begin{array}{l}D \\
0.757\end{array}$ & $\begin{array}{l}\mathrm{E} \\
0.649\end{array}$ & $\begin{array}{l}F \\
0.492\end{array}$ & $\begin{array}{l}\text { G } \\
0.333\end{array}$ \\
\hline Strip 5 & $\begin{array}{l}\text { G } \\
0.659\end{array}$ & $\begin{array}{l}\mathrm{H} \\
0.358\end{array}$ & $\begin{array}{l}\text { I } \\
0.298\end{array}$ & $\begin{array}{l}\mathrm{J} \\
0.186\end{array}$ & $\begin{array}{l}\text { A } \\
0.846\end{array}$ & $\begin{array}{l}\text { B } \\
0.803\end{array}$ & $\begin{array}{l}C \\
0.920\end{array}$ & $\begin{array}{l}D \\
0.747\end{array}$ & $\begin{array}{l}\mathrm{E} \\
0.643\end{array}$ & $\begin{array}{l}\mathrm{F} \\
0.571\end{array}$ \\
\hline Strip 6 & $\begin{array}{l}F \\
0.580\end{array}$ & $\begin{array}{l}G \\
0.386\end{array}$ & $\begin{array}{l}\mathrm{H} \\
0.317\end{array}$ & $\begin{array}{l}I \\
0.284\end{array}$ & $\begin{array}{l}J \\
0.183\end{array}$ & $\begin{array}{l}\text { A } \\
0.735\end{array}$ & $\begin{array}{l}\text { B } \\
0.821\end{array}$ & $\begin{array}{l}C \\
0.753\end{array}$ & $\begin{array}{l}\text { D } \\
0.637\end{array}$ & $\begin{array}{l}E \\
0.585\end{array}$ \\
\hline Strip 7 & $\begin{array}{l}E \\
0.869\end{array}$ & $\begin{array}{l}F \\
0.606\end{array}$ & $\begin{array}{l}G \\
0.463\end{array}$ & $\begin{array}{l}H \\
0.361\end{array}$ & $\begin{array}{l}\text { I } \\
0.283\end{array}$ & $\begin{array}{l}\mathrm{J} \\
0.185\end{array}$ & $\begin{array}{l}A \\
0.683\end{array}$ & $\begin{array}{l}\text { B } \\
1.040\end{array}$ & $\begin{array}{l}C \\
1.060\end{array}$ & $\begin{array}{l}\mathrm{D} \\
1.023\end{array}$ \\
\hline Strip 8 & $\begin{array}{l}\mathrm{D} \\
0.606\end{array}$ & $\begin{array}{l}\mathrm{E} \\
0.543\end{array}$ & $\begin{array}{l}\text { F } \\
0.441\end{array}$ & $\begin{array}{l}\text { G } \\
0.325\end{array}$ & $\begin{array}{l}\mathrm{H} \\
0.274\end{array}$ & $\begin{array}{l}\text { I } \\
0.251\end{array}$ & $\begin{array}{l}\mathrm{J} \\
0.171\end{array}$ & $\begin{array}{l}\text { A } \\
0.870\end{array}$ & $\begin{array}{l}\mathrm{B} \\
0.823\end{array}$ & $\begin{array}{l}\mathrm{C} \\
0.698\end{array}$ \\
\hline Strip 9 & $\begin{array}{l}C \\
1.002\end{array}$ & $\begin{array}{l}\mathrm{D} \\
1.332\end{array}$ & $\begin{array}{l}E \\
1.187\end{array}$ & $\begin{array}{l}F \\
0.747\end{array}$ & $\begin{array}{l}\text { G } \\
0.542\end{array}$ & $\begin{array}{l}\mathrm{H} \\
0.433\end{array}$ & $\begin{array}{l}\text { I } \\
0.378\end{array}$ & $\begin{array}{l}\mathrm{J} \\
0.221\end{array}$ & $\begin{array}{l}\text { A } \\
1.352\end{array}$ & $\begin{array}{l}\text { B } \\
1.255\end{array}$ \\
\hline Strip 10 & $\begin{array}{l}\text { B } \\
0.755\end{array}$ & $\begin{array}{l}C \\
0.613\end{array}$ & $\begin{array}{l}D \\
0.683\end{array}$ & $\begin{array}{l}\mathrm{E} \\
0.570\end{array}$ & $\begin{array}{l}F \\
0.415\end{array}$ & $\begin{array}{l}G \\
0.361\end{array}$ & $\begin{array}{l}\mathrm{H} \\
0.327\end{array}$ & $\begin{array}{l}\text { I } \\
0.301\end{array}$ & $\begin{array}{l}\mathrm{J} \\
0.187\end{array}$ & $\begin{array}{l}\text { A } \\
0.717\end{array}$ \\
\hline
\end{tabular}

Mean

Sample 1.A $=0.933$

Sample 2.B $=0.919 \quad$ Sample 3.C $=0.854$

Sample 7.G $=0.438$

Sample $8 . \mathrm{H}=0.349$

Sample 4.D $=0.803$

Sample 5.E $:=0.691$

Sample 6.F $=0.551$

Sample 9.I $=0.313$

Sample $10 . \mathrm{J}=0.198$

\begin{tabular}{lcc}
\hline - blank & $\%$ & $\begin{array}{c}\text { Myelin basic protein } \\
(\mu \mathrm{g} / \mathrm{l})\end{array}$ \\
\hline A 0.735 & control $=0.728$ & 100 \\
B 0.721 & & \\
C 0.656 & 90.2 & 1.95 \\
D 0.605 & 83.2 & 3.91 \\
E 0.493 & 67.8 & 7.81 \\
F 0.353 & 48.4 & 15.62 \\
G 0.240 & 32.9 & 31.25 \\
H 0.151 & 20.7 & 62.50 \\
I 0.115 & 15.7 & 125.00 \\
J 0.000 & & \\
\hline
\end{tabular}

The practice of having controls on the plate with each batch of standards and unknowns gives the assay a high degree of robustness and thus enhances the confidence which can be placed in unknown values. This is particularly important when large numbers of samples are being analysed.

\section{Assay of myelin basic protein in plasma}

Table 2 shows the data obtained from an experiment which used ten cuvette strips to generate a standard curve for the myelin basic protein assay. Table 1 shows the data obtained on another occasion when all ten sample positions were used for controls. The coefficient of variation (CV) of the mean values within the typical ten strip array of table 1 was $2.4 \%$. The $\mathrm{CV}$ of the mean of the two controls on a batch of 10 plates would therefore

$$
=\frac{2.4}{\sqrt{2}}=1.69 \%
$$

The parameter which was to be calculated for each sample i.e.

$$
\left(\frac{\text { mean value for sample }}{\text { mean value for controls }} \times 100\right)
$$


is the ratio of two values each with different error. The $\mathrm{CV}$ of the ratio can be calculated from statistical theory as

$$
\sqrt{\left(\frac{2.4}{100}\right)^{2}+\left(\frac{1.69}{100}\right)^{2}}=2.94 \%
$$

Thus any sample which in a given $10 \times 10$ array gave a value less than $94 \%$ of the mean of the controls would be significantly different from the control $(p=0.05)$. The detection limit of the assay shown in figure 4 and table 2 is therefore around $1.5 \mu \mathrm{g} / \mathrm{l}$ of plasma.

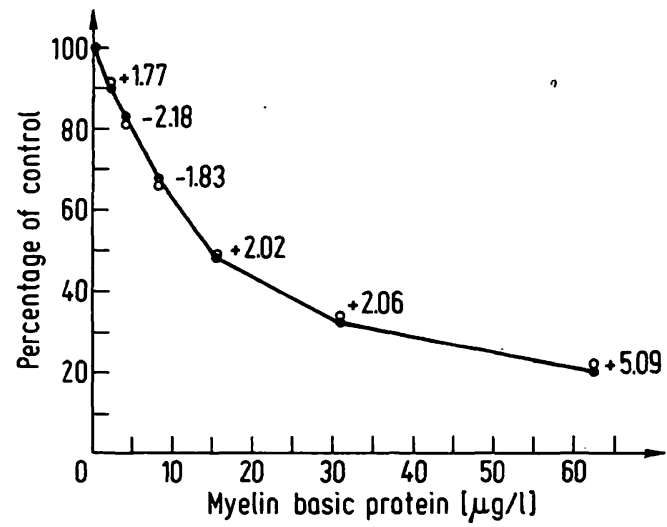

Fig. 4. Standard curve for plasma myelin basic protein assay.

- actual experimental points.

o computer fitted points after curve fitting to Equation 1 by non linear regression analysis. Regression constants:

$a=5.35 \quad b=1296 c=12.28$

The figure above each point indicates the percentage difference between actual and predicted values at each dose level.

\section{Dose interpolation}

Figure 4 shows a direct plot of (\% of control) versus myelin basic protein concentration from the data of table 2. Figure 5 shows the same data plotted on Logitlog graph paper. Good linearisation was found from 2-60 $\mu \mathrm{g} / \mathrm{l}$ myelin basic protein. Figure 4 also shows computer fitted points for the same data. The equation fitted is:

$$
y=\frac{(a x+b)}{x+c}
$$

where

$$
y=\text { percentage of control }
$$

$\mathrm{x}=$ concentration of myelin basic protein $(\mu \mathrm{g} / \mathrm{l})$ $a, b, c=$ constants fitted by the computer

The percentage differences between each experimental point and the fitted curve are shown on the graph. The myelin basic protein concentrations in unknown samples were now readily determined from equation 1 .

\section{Estimation of error in unknown values}

Since the response parameter (\% of control) has a CV of approx. $3 \%$ its value for each unknown will have $95 \%$ confidence limits $6 \%$ above and $6 \%$ below the actual value. The estimated maximum $(p \doteqdot 0.05)$ minimum $(p=0.05)$ and mean myelin basic protein concentration were then determined, for each unknown, from the standard curve. Because of the shape of the dose response relationship the upper and lower confidence limits on unknown myelin basic protein concentrations were not symmetrical about the mean.

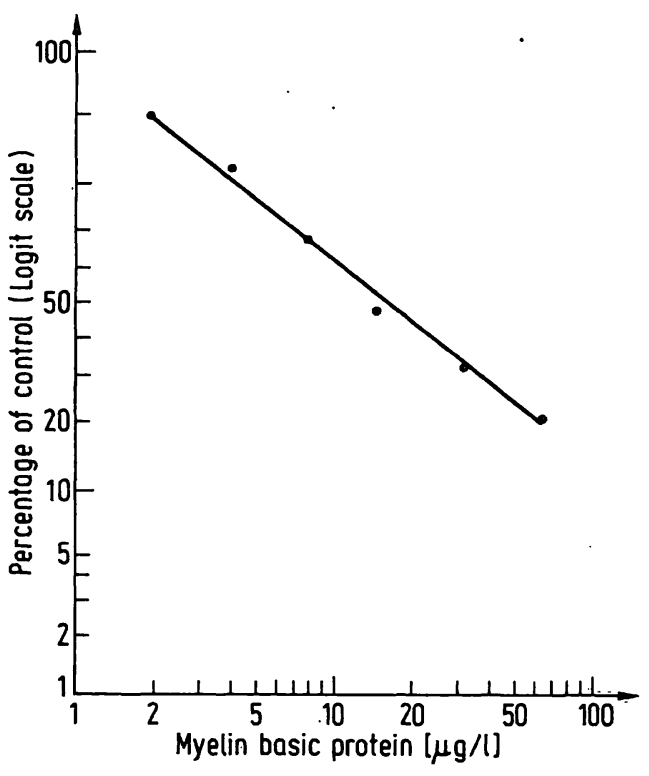

Fig. 5. Logit-log plot of myelin basic protein ELISA data.

\section{Discussion}

Enzyme linked immunoadsorbent assays based on antigen adsorption to polystyrene can be used for antigen and antibody assay using a variety of different principles (8). However, any worker who has tried quantitative ELISA's using microtitre plates will be familiar with the frustrating problems of achieving long term consistency of results.

It has been shown that wells near the edges of the plates often give abnormally high readings and that there is often a non random distribution of readings within the plate $(10,11)$. Between batch variability can be considerable as the manufacturers quality control procedures rarely include tests of protein binding (11). Selection of an acceptable batch of microtitre plates $(10)$ is complicated by the fact that manufacturers may occasionally pool batches for distribution.

Given such published information and the verbal wisdom of those who have learned first hand it will be surprising if microtitre plates retain their advocates for quantitative ELISA. Several manufacturers of these plates have 
attempted to divert attention from these shortcomings by developing sophisticated plate washers and through the plate reading photometers. These do not compensate for the above defects which stem from the difficulty of moulding large polystyrene structures reproducibly.

Gilford Instruments have recently developed a polystyrene cuvette system which serves first as a solid phase adsorbent and later as an optical cuvette for absorbance measurements. A simple manual reader for these cuvettes and a fully automated sample processor (PR50) for all the stages of ELISA are also available. A high standard of quality control is claimed for the cuvettes and each batch is tested for its protein binding characteristics.

We have found these cuvettes convenient to use. However, the 'smile' effect phenomenon described here does detract from the simplicity of their usage. It means that a permuted distribution of ten sample replicates is the only logical arrangement. However, since in microtitre plates there is no logical way to arrange replicates the Gilford cuvettes are, in our view, a significant improvement.

The 'smile' effect is believed to be due to temperature gradients which arise in each curvette strip during moulding. It is probable that its magnitude will be significantly reduced in future batches of the cuvettes. Some assay types seem to give a more marked 'smile' than others (Groome, unpublished).

The ELISA for plasma myelin basic protein works well and has several advantages over radioimmunoassay as a possible routine tool in neuropathology (4). The acid extraction procedure of Delassalle et al. (6) is valuable and removes many irrelevant plasma components. These can sometimes interfere with ELISA's on low dilution of serum or plasma (12).

Workers interested in the future developments in ELISA methodology should note that it is also possible to adsorb antigens to polystyrene spheres or couple them covalently to nylon (13).

ELISA's based on such solid phase supports may overcome the disadvantages of the currently available moulded polystyrene formats in providing a randomly distributed binding capacity.

\section{Acknowledgements}

The author is grateful to Mr. C. D. Plews of the Computer Centre, Oxford Polytechnic, for writing the data handling programs, and Mr.D. Whitely of Oxford Poly technic for preparing the figures.

\section{References}

1. Rumbsy, M. G. (1978) Biochem. Soc. Trans. 6, 448-463.

2. Palfreyman, J. W., Thomas, D. G. T. \& Ratcliffe, J. G. (1978) Clin. Chim. Acta 82, 259-270.

3. Whittaker, J. N., Lisak, R. P., Bashir, R. M., Fitch, O. M., Seyer, J. M., Kranc, R., Lawrence, J. A., Chien, L. T. \& O'Sullivan, P. (1980) Ann. Neurol. 7, 58-64.

4. Groome, N. P. (1980) J. Neurochem. 35, 1409-1417.

5. Lehtonen, O. P. \& Viljanen, M. K. (1980) J. Imm. Methods 34, 61-70.

6. Delassalle, A., Jacque, B., Drouet, J., Raoul, M., Legrand, J. C. \& Cessalin, F. (1980) Biochemie 62, 159-165.

7. Taljedal, I. B. \& Wold, S. (1970) Biochem. J. 119, 139-143.
8. Schuurs, A. H. W. M. \& Van Weemen, B. K. (1977) Clin. Chim. Acta 81, 1-40.

9. Ness, P. M. \& Perkins, M. A. (1979) Thrombos. Haemostas. (Stuttg) 42, 848-854.

10. Denmark, J. R. \& Chessum, B. S. (1978) Lancet $I, 161$.

11. Kricka, L. J., Carter, T. J. N., Burt, S. M., Kennedy, J. H., Holdor, R. L., Halliday, M., Telford, M. E. \& Wisdom, G. B. (1980) Clin. Chem. 26, 741-744.

12. Belanger, L. (1978) Scand. J. Immunol. 8, Suppl. 7, 33-41.

13. Hendry, R. M. \& Herrmann, J. E. (1980) J. Imm. Methods $35,285-296$.
N. P. Groome

Department of Biology, Oxford Polytechnic Headlington Oxford. OX3 OBP United Kingdom 


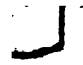

